\title{
Productivity Evaluation of r1700 Idh (load haul dump) to Meet Locomotive Productivity in Haulage Level in Underground Mine Grasberg Block Cave (gbc) PT. Freeport Indonesia
}

\author{
Jecklin Sitaniapessy $^{1}$, R. Andy Erwin Wijaya ${ }^{2}$, AA Inung Arie Adnyano ${ }^{3}$ \\ \{ Sjecklyn@yahoo.com, andyerwin@itny.ac. Id, inungarie@itny.ac.id \} \\ Department of Mining Engineering Faculty of Mineral Technology Yogyakarta National \\ Institute of Technology Yogyakarta, Indonesia
}

\begin{abstract}
PT. Freeport Indonesia is one of the first mining companies in Indonesia to engage in world-class copper, gold and silver mining, located in Tembagapura, Regency Mimika, Papua Province. The company PT. Freeport Indonesia in its operations uses an open mining system (Surface Mining) and underground mining (Underground Mining). Grasberg block cave underground mine is one of the future mines of PT. The Freeport Indonesia mine has ore reserves of 874 billion tons with a copper content of $1.04 \%$, gold 0.81 gram / tonne and silver 2.9 grams / tonne and to extract these ore reserves the Grasberg Block Cave underground mine applies the block cave method. (collapsed) but since the opening of the Grasberg Block Cave mine in 2008 until now the mine is still in the development stage. Basically, this increase in production can be achieved in two ways, firstly it can be done by maximizing the productivity of the existing R1700 LHD (Load Haul Dump) tool, and the second way that can be done is by using the addition of heavy equipment and production support tools so that production capacity to be bigger. With such a situation, it is necessary to study the calculation of productivity or the addition of the GBC (Grasberg Block Cave) underground mining equipment of PT. Freeport Indonesia, so that production can run evenly, smoothly and in accordance with the existing draworder. The purpose of this study was to determine the comparison of the productivity of the LHD (Load Haul Dump) tool R1700 at the extraction level with the locomotive productivity at the haulage level. To find out the obstacles that cause productivity of the LHD R1700 is not optimal. Optimizing the performance of the R1700 LHD (Load Haul Dump) in terms of operating hours and road conditions on the panel. Overburden stripping production target at PT. Freeport Indonesia amounted to 166,666 tonnes / hour and pershif 2000,000 tonnes / shift while the actual production of transportation equipment was 41,405 tonnes / hour per logan, but if 5 logan was 207,025 tonnes / hour, there was still a shortage of production where the mechanical equipment that had not been operated. work optimally. Based on the results of research conducted at PT. Freeport Indonesia, the work efficiency value is $79 \%$ or 0.79 work efficiency. The swell factor is obtained from the ratio of loose density to in situ density. From the data obtained from PT. Freeport Indonesia is 0.8 . In Block Civing mining activities using the LHD (Load Haul Dump) unit R1700, the total production of 1 (one) unit of loading equipment is 117,431 tons / hour and in Block Civing
\end{abstract}




\begin{abstract}
mining activities using 1 (one) Locomotive of 33,124 tons / hour and using 5 The carriage is 165,620 tons / hour. Meanwhile, the improved production from the calculation of the research results obtained total production for loading equipment of 128.682 tonnes / hour and total production of transportation equipment of 36.298 tonnes / hour and at 5 logan was 181.488 tonnes / hour, so it was known if the target had been met. The method used to meet the target is to analyze and make improvements to the factors that affect the work of the tool. Based on the results of observations and field data processing, mining activities carried out by PT. Freeport Indonesia has a production target of 4000,000 tonnes / day, 2000,000 tonnes / shift and 166,666 tonnes / hour with average real production yields in October and December 2018.
\end{abstract}

Keywords: Production, Loading Equipment, Transport Equipment, Efficiency.

\title{
1 Introduction
}

PT. Freeport Indonesia is one of the first mining companies in Indonesia to engage in worldclass copper, gold and silver mining, located in Tembagapura, Regency Mimika, Papua Province. The company PT. Freeport Indonesia in its operations uses an open mining system (Surface Mining) and underground mining (Underground Mining). Underground mine Grasberg block cave is one of the future mine PT. The Freeport Indonesia mine has ore reserves of 874 billion tons with a copper content of $1.04 \%$, gold 0.81 gram / tonne and silver 2.9 grams / tonne and to extract these ore reserves theunderground Grasberg Block Cavemine applies themethod. block cave (collapsed) but since the opening of themine Grasberg Block Cave in 2008 until now the mine is still in thestage development. In september 2018 GBC(GrasbergBlock Cave) has carried out commissioning the production process. The commissioning itself is a trial of the ore extraction process starting from thelevel undercut to the stockpile on the surface. The extracted ore is ore that is produced from theprocess development and transported using LHD (Load Haul Dump) at thelevel extraction and using Locomotive at thelevel haulage.

Basically, this increase in production can be achieved in two ways, firstly it can be done by maximizing the productivity ofLHD (Load Haul Dumpthe existing R1700) tool, and the second way that can be done is by using the addition of heavy equipment and production support tools so that production capacity to be bigger. Increased productivity from the LHD (Load Haul Dump) R1700, which is a relatively cheaper way compared to adding new heavy equipment that requires investment. One of the keys to increasing the productivity ofLHD (Load Haul Dump) the existing R1700tool is by understanding the cycle time operatingof a tool.

With such a situation, it is necessary to make a study of productivity calculations or the addition of the GBC (underground mining equipment ofGrasberg Block Cave) PT. Freeport Indonesia, so that production can run evenly, smoothly and in accordance with draworder the existing.

\section{Text formatting}

To discuss problems regarding the Evaluation of LHD Device Productivity (Load Haul Dump) R1700 in Gold and Copper Ore Mining Activities in an Effort to Increase Production Targets at Underground Mines in the Grasberg Block Cave (GBC) Area at PT. Freeport Indonesia, There 
are several work steps carried out in order to obtain the following data: This activity is to determine the comparison between the productivity of the loader at thelevel extraction and theproductivity locomotive at thelevel haulage. At this stage, data collection includes data on the cycle time for the transportation of theequipment LHD (Load Haul Dump) R1700 and locomotive. Retrieval of primary data, consisting of: data collection Cycle timeand distance traveled from the digging tool LHD (Load Haul Dump) R1700 and locomotive. Retrieval of time data retrieval that affects the productivity of LHD (Load Haul Dump) R1700 and locomotive. data is supporting data from primary data. Secondary data obtained from literature, existing research reports, archives from companies, consisting of:: Administrative maps, Location map of research area, Topographic maps, Ore extraction distance,mSituation map and lithology map at thelevel area extraction in Grasberg Block Cave (GBC). LHD specific (Load Haul Dump) R1700 and locomotive. LHD SOP (Load Haul Dump) R1700 and locomotive. processing is done by calculating the cycle time of the digging tool, the time of the drag, the productivity of the LHD (Load Haul Dump) R1700 and locomotive. Analysis is carried out to provide evaluations and recommendations to the company from various aspects. To increase the productivity and production of LHD (Load Haul Dump) R1700 and locomotive when operating with several influencing factors.

\section{Result}

productivity of mechanical equipment is not only influenced by physical and mechanical conditions, but also by the conditions in which the equipment is used. To determine the production of loading and transportation means, it is necessary to observe the factors that influence it. So that mining at PT. Freeport Indonesia.Underground Mine Grasberg Block Cave (GBC)from the extraction level site to theshedding Loco haulage levelsite using a combination of LHD tools (Load Haul Dump) R1700 andconveyances Locomotive. Time Effective uptime is the time that is actually used by the operator with the tools used for production operations. Effective working time affects work efficiency. In fact, in the field the available working time cannot be fully utilized because of the constraints that can reduce working time. Based on theworking arrangements have been set events in one day with two shifts where theshift morningand theshift. night In this research, it was only conducted in the shift morningdue to a request from the company.

Details of the work time used for 1 week at PT. Freeport Indonesia in its mining activities can be seen in table 3.1.Please follow the formatting instructions for headings given in Table 1.

Table 1. Available Working Hours

\begin{tabular}{ccccccc}
\hline \multicolumn{7}{c}{ WORK HOURS AVAILABLE } \\
\hline \multicolumn{7}{c}{ SHIFT- MORNING } \\
\hline THE & \multicolumn{3}{c}{ AT } & HOU & OF & DURATION \\
\cline { 2 - 4 } & Morning & Afternoon & RS & \\
\hline MONDAY - SATURDAY & $4: 00$ & $16: 00$ & 12 & HOU & 5040.0000 \\
& & & & RS & \\
\hline
\end{tabular}




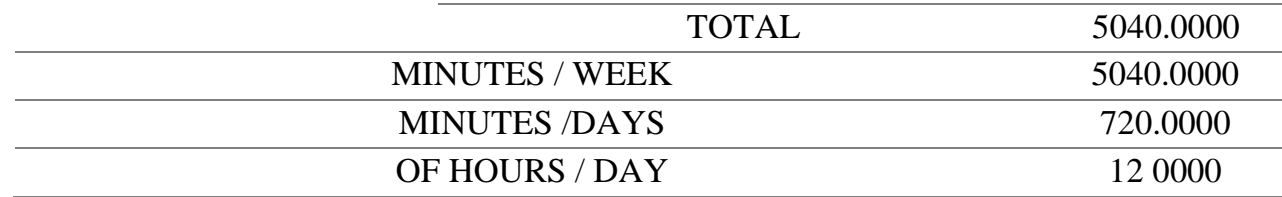

Time of Constraints

In gold mining activities, there is an effective working time where this time is obtained from the time available minus the amount of time the obstacles take place during the activity. The obstacles that occur consist of obstacles that can be avoided and obstacles that cannot be avoided, namely:can be avoided

a. Obstacles that.

Barriers that can be avoided are obstacles that occur because of deviations from the scheduled work time.

b. Is an obstacle that occurs during working hours that causes loss of working time.

The magnitude of the obstacles that can be avoided or unavoidable for the digging tool per day can be seen in the table. The size of the loading tool barriers is obtained by observing directly in the field which can be seen in Table 2

Table 2. Work ConstraintsWork

\begin{tabular}{cc}
\hline Obstacles Can Be Avoided & Actual Minutes \\
\hline Returning Early & 25 \\
\hline Check the vehicle Round & 10 \\
\hline Parking & 10 \\
\hline Total & 45 \\
\hline Barriers Can not Be avoided & Actual \\
& Minutes \\
\hline MeetingCrew & 20 \\
\hline Daily Service & 30 \\
\hline
\end{tabular}




\begin{tabular}{cc}
\hline Rest Spot & 40 \\
\hline Thermal Engineering & 15 \\
\hline number & 105 \\
\hline Total & 150 \\
\hline
\end{tabular}

efficiency is the ratio between the time spent working with the total time available. Work efficiency can be used to assess whether a job is good or not, work efficiency is influenced by the effective working time and available work time. Based on the results of research conducted at PT. Freeport Indonesia, the work efficiency value is $79 \%$ or 0.79 work efficiency.

Formula: $\mathrm{We}=\mathrm{Wt}-(\mathrm{Whd}+\mathrm{Wtd})$

Where:

We = Effective working time

$\mathrm{Wt}=$ Available working time

Whd = Time obstacles can be avoided

Wtd = Time obstacles cannot be avoided

Note:

$\mathrm{Wt}=720 \mathrm{Min}$

Whd $=85$ Minutes

Wtd $=65$ Minutes

Completion:

$\mathrm{We}=720-(85+65)$

$=570$ Minutes

b. Calculation of Work Efficiency

Formula: $\mathrm{ek}=\mathrm{we} / \mathrm{wt} \times 100 \%$

Where:

we = Effective working time

wt = Available working time

ek $\quad=$ Work efficiency

Known:

we $\quad=570$ Minutes

wt $=720$ Minutes

Solution:

$\mathrm{ek}=570 / 720 \times 100 \%$

$=0.79 \%$

$=79 \%$ 
Production of Productionof loading and transportation means is the amount of production that can be achieved in the working reality of the loading equipment and transportation equipment based on current conditions that can be achieved. From research data conducted at PT. Freeport Indonesia obtained the following production data: Inmining activities Block Civing using LHD units (Load Haul Dump) R1700, the total production of 1 (one) unit of loading equipment is 117,431 tons / hour. And the total production pershift is 1115,592 tons /shift.

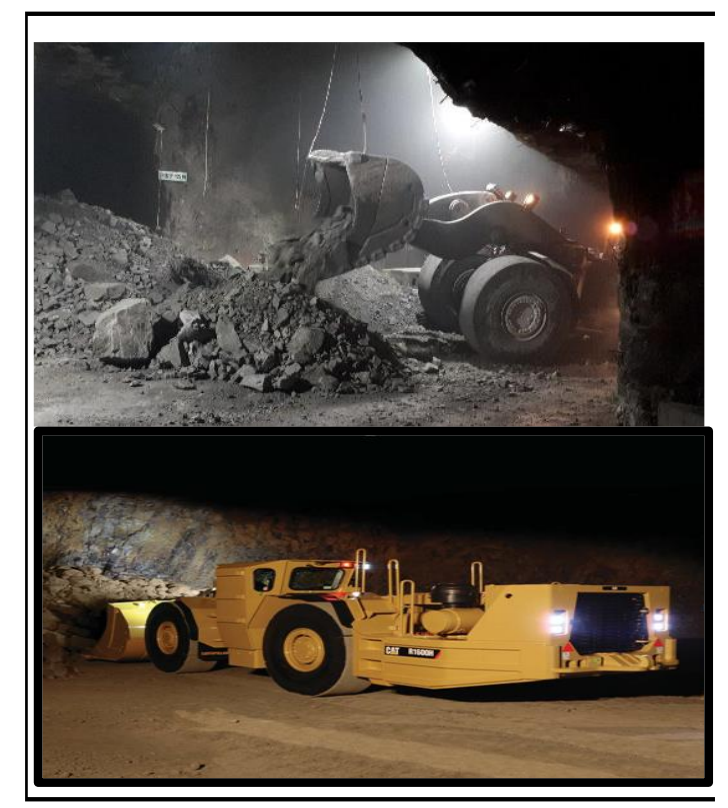

Fig. 1. Production of LHD (Load Haul Dump) R1700

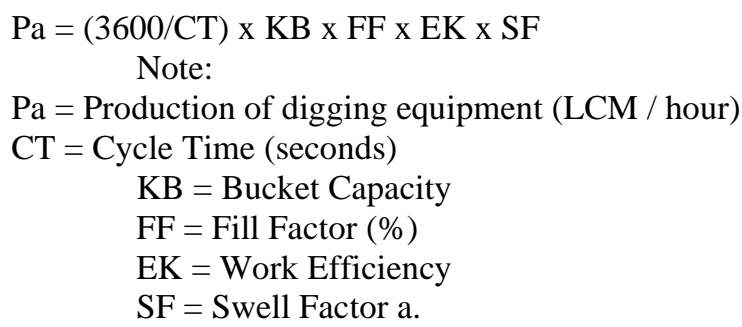

Actual production calculation for loading and unloading equipment $\mathrm{Pa}=(3600 / \mathrm{CT}) \times \mathrm{KB} \times \mathrm{FF} \times \mathrm{EK} \times \mathrm{SF}$

Where:

$\mathrm{CT}=176.63$ Minutes

$\mathrm{KB} \quad=11.97 \mathrm{Ton}$

$\mathrm{FF} \quad=0.80 \%$

$\mathrm{EC} \quad=0.79 \%$

$\mathrm{SF} \quad=0.8$ 
Solution:

$\mathrm{Pa}=(3600 / 176.63) \times 5.7 \times 0.80 \times 0.79 \times 0.8$

$=117.431$ tons $/$ hour $(1$ unit $)$

$=1115.592$ tons $/$ shif ( 1 unit)

real production load trencher is 117.431 tons / hour, Targetproductivity to meet the capacity of Locomotive 33.124 tons / h or 5 Logan amounted to 165.620 tons / hour, Where The working LHD 1700R has not reached the capacity of thedevice Locomotive.

Inmining activities Block Civing using 1 (one) Locomotive of 33,124 tons / hour and using 5 carriages of 165,620 tons / hour. The total number of transportation means atmining GBC is 1 (one) Locomotive unit and 5 (five) carriages, the total production of transportation equipment is 1573,391 tons /shift.

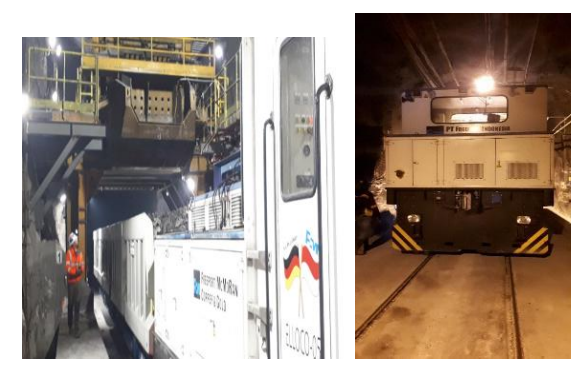

Fig. 2. Locomotive Production

The actual or actual production capacity of aconveyance Locomotive uses the following equation:

$\mathrm{Pb}=(60 / \mathrm{CTa}) \times \mathrm{Ca} \times \mathrm{EK} \times \mathrm{SF} \times \mathrm{D}$

Description:

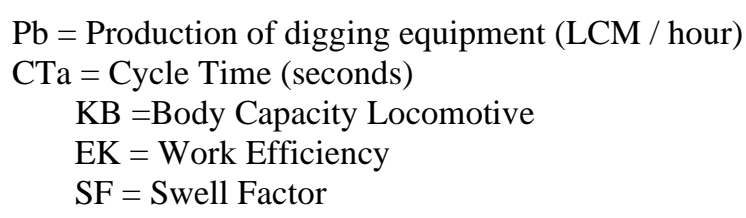

Calculation of conveyance production:

$\mathrm{Pb}=(60 / \mathrm{CTa}) \times \mathrm{KB} \times \mathrm{EK} \times \mathrm{SF}:$

Where

$\begin{array}{ll}\mathrm{CTa} & =28 \text { Minutes } \\ \mathrm{KB} & =32 \text { ton } \\ \mathrm{EK} & =0.79 \% \\ \mathrm{SF} & =0.8 \\ \mathrm{FF} & =0.8\end{array}$

Solution: 


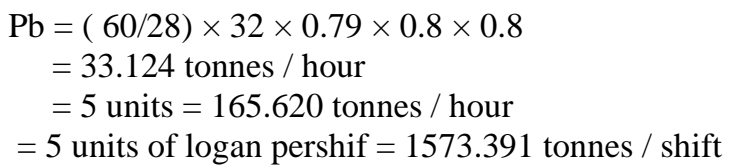

\section{Conclusion}

The real production of conveyances at each loading point is 33.124 tonnes / hour or 5 logans 165.620 tonnes / hour. Productivity target to meet LHD capacity of 117,431 tons / hour. Where the digging tool has not yet reached its productivity.

From the results of the analysis of the production of mechanical equipment operated at the open pit mine of PT. Freeport Indonesia, then we can conclude them as follows: Target production for mining ore(Ore)gold is 400,000 tons / day, 2000,000 tons / shif and 166666 tons / hour production target has not been achieved because there are barriers that occur both from human factors such as being late for work, resting too early, stopping work before it's time to go home. as well as from the tool factor, namely mechanical equipment damage The work efficiency of the equipment in the shift is morningcurrently $79 \%$. The increase in production after being carried out by reducing the time constraints that can be avoided is the efficiency of the work of the tools in the shift morning, which was originally $79 \%$ to $86 \%$. Increasing the work efficiency of tools by making improvements to the obstacles that can be avoided, so that the production of loading equipment increases to 117,431 tons / hour and the total production oftransportation means Locomotive to 33,124 tons / hour and 5 Logan of 165,620 tons / hour.

Efforts that can be made to meet the production target of 400,000 tonnes / day, 2000,000 tonnes / shift and 166,666 tonnes / hour, namely: Emphasize effective working time, by reducing the time constraints that can be avoided.

To achieve the production target of 400,000 tonnes / day, 2000,000 tonnes / shift and 166,666 tonnes / hour. Try to achieve the work efficiency of the tool per Shift (79\%-.86\%).

Acknowledgments. Thank you to all those who have helped and guided both the field supervisors at PT. Freeport Indonesia and supervisors at the Yogyakarta National Institute of Technology campus until finally this research and scientific work can be completed. This research can run very well so that the authors would like to thank all the leaders and employees of PT. Freeport Indonesia for the opportunity and guidance given to carry out research. 


\section{References}

[1.] PT. Freeport Indonesia. 2016. "Operating Procedure for LHD (Load Haul Dump) R1700".

[2.] PT. Freeport Indonesia, Tembagapura, Timika. www.cat.comhttp.analysis-regresi.pdf.com

[3.] Hartman, H., L., 1987, Introductory Mining Engineering, John Willey and Sons.

[4.] Indonesianto, Yanto. 2016. "Mechanical Soil Transfers". Publisher: General Mining Series, Mining Engineering Department, Yogyakarta National College of Technology. 2013. "Caterpillar Performance Handbook Edition 29". Caterpillar Inc., Peoria, Illinois, USA

[5.] Pfleider, E., P., 1968, SurfaceMining,1st Edition, The American Institute ofMining, Metallurgical and PetroleumEngineers,Inc., New York.

[6.] Partanto Prodjosumarto. (1995), Mechanical Soil Transfers, Department of Mining Engineering, ITB, Bandung.

[7.] Indonesianto, Y, 2015, Preparation for Underground Mining Development, Mining Engineering Study Program - FTM, UPN "Veteran" Yogyakarta.

[8.] Kresno, Thaib, H, Nurkhamim ,. Indonesianto, Y, 2015, Underground Mining, Mining Engineering Study Program - FTM, UPN "Veteran" Yogyakarta. 